\title{
Enzyme activity and phytoremediation using Plantago major to protect tomato plants from the contamination of cypermethrin pesticide
}

\section{Ahmed Aioub}

Zagazig University https://orcid.org/0000-0003-4066-4496

\section{Yayun Zuo}

Northwest Agriculture and Forestry University

\section{Ali A.A. Aioub}

Zagazig University Faculty of Agriculture

Zhaonong Hu ( $\sim$ Zhaonong20@gmail.com )

Northwest Agriculture and Forestry University

\section{Research Article}

Keywords: Phytoremediation, Cypermethrin, pollution, Plantago major, Solanum lycopersicum

Posted Date: February 16th, 2021

DOI: https://doi.org/10.21203/rs.3.rs-160143/v1

License: (a) (i) This work is licensed under a Creative Commons Attribution 4.0 International License. Read Full License

Version of Record: A version of this preprint was published at Environmental Science and Pollution Research on April 12th, 2021. See the published version at https://doi.org/10.1007/s11356-021-13853-2. 


\section{Abstract}

Phytoremediation is an environmentally friendly therapy to minimize soil pollution. Cypermethrin (CYP) is one of the most frequently used pyrethroid insecticides against a variety of pests. We aimed at evaluating the potential of using economic plant like tomato as a control alone and together with Plantago major (PM) for the uptake CYP residue from contaminated soil. Also, investigating the antioxidant enzymes such as (SOD, POD and CAT) in roots of PM and tomato. For the first time, we documented the role of PM as a phytoremediator to protect tomato plants from the contamination of CYP pesticide. In a pot experiment, we have cultivated PM and tomato in a soil polluted with CYP $\left(10 \mu \mathrm{g} \mathrm{g}^{-1}\right)$. Data showed that PM and tomato accumulated a significant amounts of CYP in their tissues. However, PM is better than tomato in uptake CYP from soil. The longest half-life value $\left(t_{1 / 2}\right)$ of CYP was in PM + tomato together treatment (12.7 days), and the shortest was in the soil with tomato alone (6.81 days). Moreover, the activity of SOD, POD and CAT in treated tomato and PM roots significantly $(p>0.05)$ exceeded control plants after 8 days from exposure. In this study, a good strategy was recommended to uptake CYP residue from soil by PM and protect tomato plants from CYP residue and also safe the human and nontarget organisms.

\section{Introduction}

Cypermethrin (CYP) is a poisonous manmade chemical chemical compound that is used to control many insects by pyrethroid in crops worldwide (Fernandez-Alvarez et al., 2009; Jin et al., 2010; Aioub et al., 2020). CYP has carcinogenic and cocarcinogens and can contain compounds such as 3-phenoxybenzoic acid with endocrine activity (Morgan et al., 2007), and oestrogenic activity (Mohammed and Hanumant 2011). The hydrophobic properties of pyrethroids typically cause soil particles to be highly sportive, which can cause binding residues to form (Ostiz and Khan 1994) and make CYP very immobile in soil because of its high log KOC value (soil adsorption coefficient) (Fenoll et al., 2010). In addition, the environmental destiny of CYP in ambient conditions is regulated by abiotic factor, for example, temperature, redox potential, pH, moisture, organic matter content and light intensity (Carvalho 2017; Meyer et al., 2013). A very high octanol-water partition coefficient has been reported for CYP $\left(\right.$ Kow $\left.=3.98 \times 10^{6}\right)$. Consequently, it strictly binds to organic matter (Conte et al., 2005). This pesticide therefore causes high soil pollution and affects non-target species. No studies on the remediation of CYP-contaminated soils were released to date.

Pollutants would reach the food chain easily if soils polluted with pesticides were used to grow food crops (Wang et al. 2003). The study of the destiny and effect of pesticides on ecosystem components is very relevant (Swaileh et al. 2001). Many experiments, including leaching, soil substitution and soil alteration, have been carried out (Wang et al. 2003) and remediation (Ximenez-Embum et al. 2001). However, costly approaches and permanent environmental degradation have been done (XimenezEmbum et al. 2001). 
Phytoremediation is used to extract and monitor pollutants or to promote the splitting of rhizospherebased microorganisms by plants, fungi and algae (McCutcheon and Schnoor 2003). This technology is designed to use plants and associated micro-organisms to treat groundwater and contaminated soils (Schwitzguébel and Schröder 2009; Yanyu et al. 2010; Khan et al. 2014). While plants were described in1950, but the word 'phytoremediation' use was coined in1991, considerable progress was reported between 1991 and 2003 to recover radionuclide contaminated soil (Romney et al. 1957; McCutcheon and Schnoor 2003; Willey, 2007; Gerhardt et al. 2009). Phytoremediation has now achieved the status of a validated technique for cleaning the soil and groundwater polluted with different organic contaminants (Aken et al., 2010). Phytoremediation of plant and wetland pesticides on plant function alone (using the plant to uptake the toxic compounds from soil) or in synergism with bacteria such as rhizospheric and endophytic, has been mentioned in many papers (Miglioranzaet al., 2004; Calvelo-Pereira et al. 2006; Abhilash et al. 2011; Becerra-Castro et al. 2013; Miguel et al., 2013).

Plantago major (PM) called plantain plant is a well-known perennial herb that grows in many areas such as the meadowland, roadsides, fields developed, canal water and waste zones (Sharifa et al., 2008). The broad surface area of their fibrous roots and their phytoremediation capability has used PM as a curative plant (Romeh 2010; Romeh 2015; Romeh 2016; Aioub et al., 2019). Chekol et al., (2002) mentioned that intense soil penetration has to do with a wide fibrous roots surface. Terrestrial grasses are most commonly used in organic compounds remediation.

There is growing evidence that intracellular overproduction by reactive oxygen (ROS) can cause harm to plant cells (Peixoto et al., 2006). Plants have evolved a number of defensive mechanisms to prevent or mitigate damage to ROS. The enzymatic antioxidant mechanism is a defensive system including some enzymes like superoxide dismutase (SOD), catalase (CAT) and peroxidase (POD). ROS formation is a frequent occurrence in stressful compounds and is dependent both on enzyme and non-enzyme reactions (Mithofer et al. 2004). The increased level of ROS allows antioxidant waterfall pathways to be triggered (Agrawal et al. 2002). ROS scavenging systems such as SOD stimulates the dismutation of $\mathrm{H}_{2} \mathrm{O}_{2}$ (Hydrogen peroxides). $\mathrm{H}_{2} \mathrm{O}_{2}$ by different scavenging enzymes is concurrently converted into water and oxygen. In general, the stress mechanism of toxic compounds is linked to the production of reactive oxygen, jasmonate and ethylene signaling pathways (Maksymiec 2007).

Some studies were caring out with some pesticides, including accumulation in rice plants of atrazine, led to toxic reactions as over generation of ROS, activating the safety mechanism for plants (Zhang et al., 2014). In another study, (Yin et al. 2008) reported that isoproturon, which causes the delay in wheat plant growth and also affects many physiological processes since oxidation stress is caused, whereas wheat plants have been activated to diminish ROS by different antioxidant enzymes, including SOD, CAT and POD.

Although the phytoremediation efficiency of PM combined with surfactant is a marvel solution for soil contaminated CYP. So, we want to evaluate if PM can be used to remediated soil contamination crop growing field such as tomato field by CYP contaminated. Therefore, we choose tomato as a research crop 
using PM for evaluating the remediation possibility. Therefore, the present study investigated the CYP uptake and distribution in PM alone and together with tomato as a control in contaminated soils and ability of PM in protects tomato from the contamination with CYP. Also, evaluation of the response of the enzymatic antioxidant system in the roots of tomato (Solanum lycopersicum Mill.) and PM as a result of CYP contaminated by using the SOD, CAT, POD, H2O2 parameters.

\section{Materials And Methods}

\subsection{Pesticide and plants}

The CYP (99\%) reference standard was bought from Sigma, China. After planting, CYP was dissolved in acetone $(0.5 \mathrm{~mL})$ to get $10 \mu \mathrm{g} \mathrm{g}^{-1}$ concentrations. CYP was added in the soil of the irrigation water pots at this concentration to prevent the direct contact between CYP and plant shoots.

PM and tomato seeds were bought from a local market (Shangcheng, $31^{\circ} 47^{\prime} 43^{\prime \prime} \mathrm{N}, 115^{\circ} 24^{\prime} 4^{\prime \prime} \mathrm{E}$, Henan Province, China). The winter of 2018 was seeded with PM and tomato seeds in trays. The plants were thinned to a single plant and moved into pots after germination.

\subsection{Phytoremediation experiment setup}

The experiment of pots was carried out at the Institute of Pesticide Science, College of Plant Protection, Northwest A\&F University, Yangling, Shaanxi Province, China under greenhouse conditions. The experiment was carried out under the conditions of natural light since the temperature and the relative humidity in the greenhouse were $25-27^{\circ} \mathrm{C}$ and $66-69 \%$, respectively. "For this experiment, the soil was collected from a plot in Yangling ( $\left.34^{\circ} 17^{\prime} 2^{\prime \prime} \mathrm{N}, 108^{\circ} 3^{\prime} 50^{\prime \prime} \mathrm{E}\right)$, Shaanxi Province, China. The sieved clay loamy soil was air dried (organic matter $18.2 \mathrm{~g} \mathrm{~kg}^{-1}, \mathrm{pH} 7.3$, and electric conductivity $2.28 \mathrm{~S} \mathrm{~m}^{-1}$ ) then put in plastic pots. Each plastic pot has earned five hundred grams of soil. Before the end of the growing season, the soil moisture level was modified to near the soil field potential." The experimental pots were randomly configured to consist of six treatments: (1) C: CYP-contaminated soil (CCS) without plants, (2) T2: CCS with PM only, (3) T3: CCS with tomato only, (4) T4: CCS with PM and Tomato, (5) T5: CCS with PM then after 7 days put tomato, (6) T6: CCS with tomato then after 7 days put PM. For all treatments, 90 pots were used; each treatment consists of 15 pots and three replicates for each treatment for five different sample collection periods. One plant has been cultivated for 14 days in each pot. Plants were obtained from the polluted soil to be analysis after 1, 3, 7, 10 and 14 days after exposure period. Plants were dissected into leaves and roots. Three minutes of running water washed and then dried the plant roots and leaves. $10 \mathrm{~g}$ of soil and $4 \mathrm{~g}$ from roots and leaves were prepared to determine the CYP residues.

\subsection{Determination of CYP residue in the soil and tested plants}

CYP residue extraction was performed with the QuEChERS (quick, easy, cheap, effective, rugged and safe) method stated by Lehotay et al., (2005). In short, 10 grams of soil $4 \mathrm{~g}$ of each plant (roots and leaves), 
then $10 \mathrm{~mL}$ of acetonitrile ( $1 \%$ acetic acid) put in a $50 \mathrm{~mL}$ centrifuge tube. For one minute, the samples were forcibly shaken and subsequently added six $\mathrm{g} \mathrm{MgSO} 4,1.5 \mathrm{~g} \mathrm{NaCl}$, and one g sodium citrate tribasic dehydrate ( $\mathrm{Na} 3$ citrate). Adding the salt then each tube was shaken. They were firmly shaken one minute and subsequently centrifuged at $4000 \mathrm{U} \mathrm{min}^{-1}$ for five minutes. A $1 \mathrm{ml}$ supernatant aliquot was moved to a dispersive clean-up tube including a MgSO4, graphitized carbon black (GCB), C18 and primary secondary amine (PSA). Then shaken these tubes for 30 seconds and centrifuged at $4000 \mathrm{U} \mathrm{min}^{-1}$ for five minutes.

A GC-2014C (Shimadzu) containing a capillary column using a CYP capture detector (ECD) for Ni63 has been analyzed for the cleansed extract. The separation of CYP was performed in a $30 \mathrm{~m} \times 0.25 \mathrm{~mm}$ internal diameter, $0.25 \mu \mathrm{m}$ thickness film submerged in a $5 \%$ diphenyl, $95 \%$ methylpolysiloxane HP-5MS column. Nitrogen gas was used as a carrier at 9.6 psi pressure and two $\mathrm{mL} \mathrm{min}^{-1}$ flow. The injector had been used at $280^{\circ} \mathrm{C}$, while the temperature of the detector was $300^{\circ} \mathrm{C}$. The initial oven temperature was $110^{\circ} \mathrm{C}$ (3 min isothermal) to $275^{\circ} \mathrm{C}$. The volume of injection was $1.0 \mu \mathrm{L}$.

The soil, root and leaf samples of each plant were calculated for CYP recovery at different fortification levels, i.e., $0.05,0.1$ and $0.5 \mathrm{mg} \mathrm{kg}^{-}{ }^{1}$. We did not detect in the sample chromatogram under the selected conditions any peaks. In PM sampling (soil, root and leaves), the recoveries average ranges are 90.6$90.7 \%, 89.3-91.2 \%$ and $92.6-96.5 \%$, respectively. Whilst, tomato samples (soil, root, and leaves) were $90.6-90.7 \%, 87.31-89.12 \%$ and $85.2-85.6 \%$, respectively.

The rate of degradation $(K)$ and half-life value $\left(t_{1 / 2}\right)$ were calculated by Belal and Gomaa (1979), according to the following equation reported

The rate of degradation $(K)=2.303 \times$ slope. $(4)$

Half-life value $(\mathrm{t} 1 / 2)=0.693 . \mathrm{K}^{-1}$. (5)

\subsection{Antioxidant enzymes experiment setup}

During the 2018/2019 winter season, PM and tomato seeds were cultivated. Two seeds of PM were planted per pot in a growing chamber at normally growing temperature $\left(25^{\circ} \mathrm{C}\right)$. Each pot has $500 \mathrm{~g}$ soil. After germination in each pot, the plants were thinned to a single plant. In about one month, experiment design is consisting of three treatments: (1) PM transfer from soil and put in Hoagland solution $(250 \mathrm{~mL})$ according to (Wang 1986), containing $10 \mu \mathrm{g} \mathrm{mL}^{-1}$ of CYP in flask $500 \mathrm{~mL}$. (2) Tomato transfer from soil and put in Hoagland solution (250 mL) according to (Wang 1986), including $10 \mu \mathrm{g} \mathrm{mL}^{-1}$ of CYP in flask $500 \mathrm{~mL}$. (3) Flask with each plant alone was prepared as a control. Each treatment has three replicates., PM and tomato roots have been collected and instantly frozen into liquid nitrogen in Hoagland solution after 8 days, $100 \mathrm{mg}$ from roots were homogenized at $4{ }^{\circ} \mathrm{C}$ with liquid nitrogen and $100 \mathrm{mM}$ phosphate buffer (pH 7.0) including 1 mM EDTA, 1 mM PMSF, and 0.5\% PVP. The mixture has been centrifuged for $20 \mathrm{~min}$ at $9000 \mathrm{rpm}$. The enzyme extract supernatant was used to determine the activity of the enzyme. 


\subsection{Analysis of protective enzyme \\ 3.5.1 SOD activity}

According to Giannopolitis and Ries (1977), SOD activity (EC 1.15.1.1) was calculated by estimating its ability to inhibit the photochemical reduction of nitro-blue tetrazolium (NBT). Three milliliters of reaction mixture contained $50 \mathrm{mM}$ phosphate buffer ( $\mathrm{pH} 7.8), 10 \mathrm{mM}$ methionine, $1.17 \mathrm{mM}$ riboflavin, $56 \mathrm{mM}$ NBT, and the enzyme extract. The absorbance of this solution was measured at $560 \mathrm{~nm}$. An enzyme activity which inhibited photo-reduction the nitro-blue tetrazolium to $50 \%$ was identified as one unit of SOD.

SOD activity $(\mathrm{U} / \mathrm{g}$ fresh weight $)=11.11 \times$ Percent of inhibition $\div(1$ - Percent of inhibition $) \div \mathrm{W}$

Percent of inhibition $=($ A blank $-\mathrm{A}$ sample $) \div A$ control $\times 100$

W: sample weight.

\subsubsection{POD activity}

According to the method of Cakmak and Marschner (1992), the POD activities (EC1.11.1.7) were estimated with some modifications. The reaction mixture $(3 \mathrm{ml})$ consisted of $100 \mu \mathrm{L}$ enzyme extract, 100 $\mu \mathrm{L}$ guaiacol $(1.5 \%, \mathrm{v} / \mathrm{v}), 100 \mu \mathrm{L} \mathrm{H} \mathrm{O}_{2}(300 \mathrm{mM})$ and $2.7 \mathrm{ml}$ of $25 \mathrm{mM}$ potassium phosphate buffer with 2 mM EDTA ( $\mathrm{pH}$ 7.0). The increase in absorption due to oxidation of guaiacol was measured at $470 \mathrm{~nm}$ by a microplate reader (SpectraMax 1340-PC; Molecular Devices, Shanghai, China). The following formula has been used in calculating enzyme activity of POD at $25 \pm 2^{\circ} \mathrm{C}$.

POD activity $(\mathrm{U} / \mathrm{g}$ fresh weight $)=4000 \times(\mathrm{A} 2-\mathrm{A} 1) \div \mathrm{W}$

A1: The activity after $1 \mathrm{~min}$

A2: The activity after $2 \mathrm{~min}$

W: sample weight

\subsubsection{CAT activity}

"Catalase (CAT, EC 1.11.1.6) activity was determined according to (Cakmak and Marschner 1992) method. In brief, A $10 \mathrm{ml}$ extraction buffer was ground (0.5M Na-phosphate, pH 7.3, 3mM EDTA, 1\% PVP, $1 \%$ Triton $X 100$ ) with $0.1 \mathrm{~g}$ of fresh leaf content and centrifuged at $10,000 \mathrm{rpm}$ at $4^{\circ} \mathrm{C}$ for 20 minutes. The assay mixture $(3 \mathrm{~mL})$ was comprised of $100 \mu \mathrm{L}$ enzyme extract, $100 \mu \mathrm{L} \mathrm{H}_{2} \mathrm{O}_{2}(300 \mathrm{mM})$ and $2.8 \mathrm{~mL}$ $50 \mathrm{mM}$ phosphate buffer with $2 \mathrm{mM}$ EDTA ( $\mathrm{pH} 7.0)$." The CAT activity was measured using the following formula by consuming $\mathrm{H}_{2} \mathrm{O}_{2}$ (extinction coefficient of $39.4 \mathrm{mM} / \mathrm{cm}$ ) at $405 \mathrm{~nm}$ for $30 \mathrm{~s}$ :

CAT activity $(\mu \mathrm{mol} / \mathrm{min} / \mathrm{g}$ fresh weight $)=444.44 \times(\Delta \mathrm{A}-0.0013) \div \mathrm{W}$

$\Delta \mathrm{A}=\mathrm{A}$ blank $-\mathrm{A}$ sample 


\subsection{3 $\mathrm{H}_{2} \mathrm{O}_{2}$ determination}

Analysis of $\mathrm{H}_{2} \mathrm{O}_{2}$ was conducted on fresh plant materials as according to Willekens et al. (1997). "The reaction mixture containing $1 \mathrm{~mL}$ enzyme extract, $1 \mathrm{~mL}$ of $10 \mathrm{mM}$ potassium phosphate buffer $(\mathrm{pH} 7.0)$ and $2 \mathrm{~mL}$ of $1 \mathrm{M} \mathrm{KI}$ was observed with absorption of $415 \mathrm{~nm}$ ". The quantity of $\mathrm{H}_{2} \mathrm{O}_{2}$ produced was expressed as $\mu \mathrm{M} / \mathrm{g}$ fresh weight $(\mathrm{FW}) . \mathrm{H}_{2} \mathrm{O}_{2}$ was calculated with following formula.

$\mathrm{H}_{2} \mathrm{O}_{2}$ content $=2.67 \times(\Delta \mathrm{A}-0.0006) \div \mathrm{W}$

$\Delta \mathrm{A}=\mathrm{A}$ sample $-\mathrm{A}$ blank

W: sample weigh.

\subsubsection{Statistical analysis}

Statistically, one-way ANOVA data were analyzed and the average values (mean \pm SD) were compared among all treatments. The CoStat $6.311 \mathrm{CoHort}$ Statistical Software was used for research purposes. The difference was considered to be significant if $p$-value was less than or equal to $0.05(p \leq 0.05)$.

\section{Results}

\subsection{Dynamics of CYP in soil and plants tested tissues}

The concentrations of CYP in the soil and plants tested tissues through the experiment are shown in Fig. 1. Data from this analysis showed a significant amount of CYP has been removed in all experimental groups containing plants. In the soil with PM and tomato, the CYP concentration were $8.24-3.16 \mathrm{~kg}^{-1}$ and $9.24-3.66 \mathrm{~kg}^{-1}$ over the $14 \mathrm{~d}$ of the experiment, respectively. In Fig. 1, it was $9.47-3.84 \mathrm{mg} \mathrm{kg}^{-1}$ in the control soil with significant $(p>0.05)$. The significant accumulation of CYP in PM + tomato roots together, $\mathrm{PM}+$ tomato roots (7 d) and tomato + PM roots (7 d) were 21.95, 17.69 and $9.02 \mathrm{~kg}^{-1}$ at 7 days compared with tomato roots only $\left(9.03 \mathrm{mg} \mathrm{kg}^{-1}\right)$, respectively (Fig. 2). On the 14th day, significant differences of CYP concentration were observed PM + tomato roots together, $\mathrm{PM}+$ tomato roots $(7 \mathrm{~d})$ and tomato + PM roots (7 days) were $34.43,32.48$ and $23.17 \mathrm{mg} \mathrm{kg}^{-1}$ compared with tomato roots alone $\left(10.37 \mathrm{mg} \mathrm{kg}^{-1}\right)$ $(p>0.05)$.No observed any concentrations of CYP in all treatment on 1, 3 days in the leaves. The concentration of uptake and translocation for CYP in PM + tomto leaves together, $\mathrm{PM}+$ tomato leaves (7days) and tomato + PM leaves (7 d) were 14.14, 12.50 and $3.67 \mathrm{mg} \mathrm{kg}^{-1}$ with significantly different ( $p$ $>0.05)$ at 7 days, respectively, compared with tomato leaves alone $\left(3.67 \mathrm{mg} \mathrm{kg}^{-1}\right)$. However, on the 14 th day, the concentrations were $25.25,21.80,9.29 \mathrm{mg} \mathrm{kg}^{-1}$, respectively, compared with tomato leaves alone (5.27 $\mathrm{mg} \mathrm{kg}^{-1}$ ) (Fig. 3).

\subsection{Residue half life time $\left(t_{1 / 2}\right)$ for CYP}


A first order reaction will sufficiently explain the removal of CYP from the soil. As shown in Fig. 4, the residue half-life values $\left(\mathrm{t}_{1 / 2}\right)$ of CYP was as follows for all treatments: $\mathrm{PM}+$ tomto together $>$ PM + tomato (7days) > tomato + PM (7 days) > tomato alone.

\subsection{Physiological characteristics}

CYP stress has contributed to major changes in both PM and tomato roots in the antioxidant defense system. In contrast to non-stressed control plants, a significant increases $(p \leq 0.05)$ in antioxidant enzyme activity (SOD, POD, and CAT) were observed in both PM and tomato roots.

The obtained data (Fig. 4a,b,c) revealed that the activity of SOD, POD and CAT in treated tomato and PM roots significantly exceeded control plants after 8 days from exposure $(p \leq 0.05)$ and the above enzyme activity increased in PM roots compared with tomato roots when exposure to CYP stress (Fig. 3). The activity of SOD, POD and CAT in PM and tomato roots under CYP stress were (11.88-8.85 $\left.\mathrm{U} \mathrm{g}^{-1}\right)$,

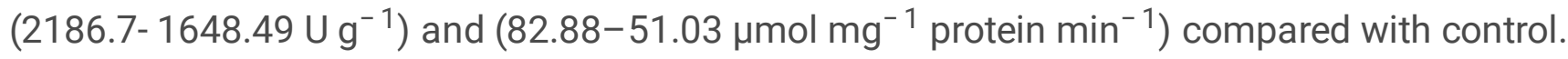

Changes in $\mathrm{H}_{2} \mathrm{O}_{2}$ content are shown in Fig. 4d. Our results show that the roots of PM and tomato significantly $(p \leq 0.05)$ greater $\mathrm{H}_{2} \mathrm{O}_{2}$ contents than control after 8 days from expousre. Also, under CYP stress, $\mathrm{PM}$ roots had greater $\mathrm{H}_{2} \mathrm{O}_{2}$ contents than was observed in the tomato roots $(p \leq 0.05)$.

\section{Discussion}

Phytoremediation is a technology which uses plants in the environment to immobilize, eliminate or process pollutants including pesticides (Matsumoto et al., 2009; Aioub et al., 2019). Based on this study, although PM and tomato accumulated significant amounts of CYP in their tissues. However, PM is better than tomato in uptake CYP from soil (Fig. 1-3). This capacity for PM is shown since the plant does not only have a wide variety of fibrous roots, often used in organic compounds remediation (Chekol et al., 2002; Azmat et al., 2009) but also bioactive substances known as polyphenolic compounds. Such compounds can be scavenged freely by using metal ion chelators and the naturalization of hazardous reactive oxidants (Zubair, 2010). These results are in harmony with Romeh (2010), who reported that PM can use roots and then the leaves to uptake imidacloprid from the soil, so PM can be used to minimize contamination in the soil by imidacloprid. Likewise, the removal of azoxystrobin in polluted soil was higher in PM than Glycine max and Helianthus annuus (Romeh 2015). Moreover, the imidacloprid fate in tomato plants was investigated through 75 days in 14C-imidacloprid-contaminated soil (Alsayeda et al., 2008). Aria et al., (2019) showed that extraction-spectrometry of ion mobility molecular an impression includes the monitoring of imidacloprid absorption and translocation in the tomato plant. PM was contributed in protect tomato plants from CYP contamination (Fig. 2, 3), but it is effect in tomato production and growth. So, phytoremediation is just use a curative method.

With regard to $\mathrm{T}_{1 / 2}$ (Fig. 4), PM and tomato can only take CYP up from the soil but not degrade CYP. Soil microbes play a significant role in CYP degradation. In the treatment of soil, the longest half-life value $\left(t_{1 / 2}\right)$ of CYP was $12.7 \mathrm{~d}$, but the shortest was in the treatment of which soil + PM + tomato (6.81 d). This 
may be attributed to the microbial degradation process, which is outlined in three sections (Kumar et al., 2018). First of all, adsorption was the goal; it went over the cell membrane surface and was also a vital dynamic balance process. Second, the target penetrated the cell membrane region and was connected to the target molecular isomer structure with the efficiency and penetration rate. Lastly, enzyme reactions in the membrane easily undergo this objective. This result was reported formerly by Romeh and Hendawi (2017), who noted that the $t_{1 / 2}$ of fenamiphos in soil with Pseudomonas fluorescens + Glycine max was $6.16 \mathrm{~d}$. Whilst, $\mathrm{t}_{1 / 2}$ in soil + Glycine max was $10.9 \mathrm{~d}$.

Numerous results have shown that plants evolved a complex antioxidant protection mechanism depending on antioxidant enzymes (SOD, POD and CAT) that clean free radicals and peroxides (Prasad et al. 2005a; Gratão et al. 2008; Gill and Tuteja 2010). Improved stress tolerance is associated in plants exposed to various stresses, in particular by increasing antioxidant enzyme activity (Gomes-Junior et al., 2006; Gratão et al., 2008; Fidalgo et al., 2011). A significant increase $(p \leq 0.05)$ in antioxidant enzymes activities (SOD, POD and CAT) was observed after 8 days in PM and tomato roots when exposure to CYP stress as compared with control treatments. Also, $\mathrm{H}_{2} \mathrm{O}_{2}$ contents $\mathrm{PM}$ and tomato roots under CYP stress was significantly greater $(p \leq 0.05)$ than roots of PM and tomato roots without CYP exposure. This is a significant increase in activity might be due to SODs are enzymes that stimulate $\mathrm{H}_{2} \mathrm{O}_{2}$ dismutation. Thus, SODs enzymes are at the front line of the defense against ROS. PODs are involved in the detoxification of $\mathrm{H}_{2} \mathrm{O}_{2}$. Moreover, hydroxylic reactions can be conducted by PODs as a second cyclic reaction; this is different from peroxidation reaction. Also, POD is participated in the degradation of $\mathrm{H} 2 \mathrm{O} 2$ and also sundry other physiological processes in plant (Bowler et al., 1992). With regard to CATs, the increase of enzyme activity under CYP stress is might be due to it stimulate $\mathrm{H}_{2} \mathrm{O}_{2}$ dismutation molecules to water and $\mathrm{O}_{2}$. This result is compatible with the previous report by (Foyer and Noctor 2005) indicated pesticideinduced toxicity caused by the generation of oxidative i.e. ROS production and its process for plant scavenging. The accumulation of ROS in the leaves of bitter gourd has been quantified when exposed to increased dimethoate pesticide concentrations (Mishra et al., 2009). In addition, Haddad et al., (2009), the use of chlorpyrifos quickened SOD activity in plants. Moreover, Parween et al., (2012) also demonstrated improved SOD activity in Vigna radiata subjected to various chlorpyrifos levels. Karadge and Karne (1985) also reported that POD activity in tomato leaves has been enhanced when exposed to different fungicide concentrations of bavistin and calixin. Parween et al. (2012) demonstrated that enhanced CAT activity in Vigna radiate L. due to the foliar application of chlorpyrifos insecticide.

\section{Conclusion}

Our current study demonstrated that CYP uptake and distribution in PM alone and together with tomato as a control in contaminated soils and ability of PM in protects tomato from the contamination with CYP. However, the present of PM effect in tomato production and growth. So, phytoremediation is just use a curative method. Moreover, the activity of SOD, POD and CAT in treated tomato and PM roots significantly $(p>0.05)$ exceeded control plants after 8 days from exposure. Therefore, phytoremediation was 
recommended as a curative method to uptake CYP residue from soil by PM and protect tomato plants from CYP residue and also safe the human and non-target organisms.

\section{Declarations}

\section{Funding}

This study was funded by the grant of National Natural Science Foundation of China (31672055) and the grant of the National Key Research and Development Program of China (2017 YFD0201402) from Science and Technology Ministry of China.

\section{Authors' contributions}

Ahmed A.A. Aioub: Conceptualization, Methodology, Software, Investigation, Resources, Data curation, writing, original Draft, visualization, project administration. Ahmed A.A. Aioub and Ali A. A. Aioub contributed to the interpretation of the results and to the writing of the manuscript. Ahmed A.A. Aioub and Yayun Zuo designed the enzyme activity assay. Zhaonong Hu supervised the study. All the authors read and approved the final manuscript.

Data availability The datasets used and/or analyzed during the current study are available from the corresponding author on reasonable request.

\section{Compliance with ethical standards}

Ethical approval Not applicable

Consent to participate Not applicable

Consent to publish Not applicable

Competing interests The authors declare that they have no competing interests.

\section{References}

Abhilash, P., Srivastava, S., Srivastava, P., Singh, B., Jafri, A., Singh, N., (2011). Influence of rhizospheric microbial inoculation and tolerant plant species on the rhizoremediation of lindane. Environ. Exp. Bot. 74, 127e-130.

Agrawal GK, Rakwal R, Jwa NS, Agrawal VP (2002) Effects of signaling molecules, protein phosphatase inhibitors and blast pathogen (Magnaporthe grisea) on the mRNA level of a rice (Oryza sativa L.) phospholipid hydroperoxide glutathione peroxidase (OsPHGPX) gene in seedling leaves. Gene 283:227236. 
Aioub, A.A.A., Li, Y., Qie, X. et al. Reduction of soil contamination by cypermethrin residues using phytoremediation with Plantago major and some surfactants. Environ Sci Eur 31, 26 (2019). https://doi.org/10.1186/s12302-019-0210-4

Aioub, A.A.A., Zuo, Y., Li, Y. et al. Transcriptome analysis of Plantago major as a phytoremediator to identify some genes related to cypermethrin detoxification. Environ Sci Pollut Res (2020). https://doi.org/10.1007/s11356-020-10774-4

Aken BV, Correa AP, Schnoor JL. 2010. Phytoremediation of Polychlorinated Biphenyls: New Trends and Promises. Environ Sci Technol 44(8):2767-2776.

Alsayeda, H., Pascal, S., Nallanthigal, C., Debrauwer, L., and Laurent, F. (2008). Transfer of the insecticide [14C] imidacloprid from soil to tomato plants. Environmental Chemistry Letters - ENVIRON CHEM LETT, 6 , 229-234. doi:10.1007/s10311-007-0121-2.

Aria, M. M., Sorribes-Soriano, A., Jafari, M. T., Nourbakhsh, F., Esteve-Turrillas, F. A., Armenta, S., . . de la Guardia, M. (2019). Uptake and translocation monitoring of imidacloprid to chili and tomato plants by molecularly imprinting extraction - ion mobility spectrometry. Microchemical Journal, 144, 195-202.

Azmat, R., Haider, S., and Riaz, M. (2009). An inverse relation between Pb2+ and Ca2+ ions accumulation in phaseolus mungo and lens culinaris under Pb stress. Pakistan Journal of Botany, 41, 2289-2295.

Becerra-Castro C, Prieto-Fernández Á, Kidd PS, Weyens N, Rodríguez-Garrido B, Touceda- González M, Acea MJ, Vangronsveld J. 2013. Improving performance of Cytisus striatus on substrates contaminated with hexachlorocyclohexane $(\mathrm{HCH})$ isomers using bacterial inoculants: developing a phytoremediation strategy. Plant Soil 362:247-260.

Belal, M. H., and Gomaa, E. A. (1979) Determination of dimethoate residue in some vegetables and cotton plants. Bull Environ Contam Toxicol22, 726-30.

Bowler C, Van Montague M, Inzé D (1992) Superoxide dismutase and stress tolerance. Annu Rev Plant Physiol Plant Mol Biol 43:83-116.

Cakmak I, Marschner H (1992) Magnesium deficiency and high light intensity enhance activities of superoxide dismutase, ascorbate peroxidase, and glutathione reductase in bean leaves. Plant Physiol 98:1222-1227.

Calvelo-Pereira R, Camps-Arbestain M, Rodríguez-Garrido B, Macías F, Monterroso C. (2006). Behaviour of $\mathrm{a}-, \beta-, \gamma_{-}$, and $\delta$-hexachlorocyclohexane in the soil-plant system of a contaminated site. Environ Pollut 144:210-217.

Chekol, T., Vough, L. R., and Chaney, R. L. (2002). Plant-Soil-Contaminant Specificity Affects Phytoremediation of Organic Contaminants. International Journal of Phytoremediation, 4(1), 17-26. doi:10.1080/15226510208500070. 
Conte, P., Agretto, A., Spaccini, R., and Piccolo, A. (2005) Soil remediation: humic acids as natural surfactants in the washings of highly contaminated soils. Environmental pollution 135, 515-522.

Fenoll, J., Ruiz, E., Flores, P., Hellín, P., and Navarro, S. (2011) Reduction of the movement and persistence of pesticides in soil through common agronomic practices. Chemosphere 85, 1375-1382.

Fernandez-Alvarez, M., Llompart, M, .Lamas, J. P., Lores, M., Garcia-Jares, C., Cela, R., and Dagnac, T. (2009) Development of a matrix solid-phase dispersion method for the simultaneous determination of pyrethroid and organochlorinated pesticides in cattle feed. Journal of Chromatography A 1216, 28322842.

Fidalgo F, Freitas R, Ferreira R, Pessoa A, Teixeira J (2011) Solanum nigrum L: antioxidant defense system isoenzymes are regulated transcriptionally and post translationally in Cd-induced stress. Environ Exp Bot 72:312-319.

Foyer CH, Noctor G (2005) Oxidant and antioxidant signaling in plants: a re-evaluation of the concept of oxidative stress in a physiological context. Plant Cell Environ 28:1056-1071.

Gerhardt KE, Huang XD, Glick BR, Greenberg BM. 2009. Phytoremediation and rhizoremediation of organic soil contaminants: Potential and challenges. Plant Sci.176:20-30.

Giannopolitis CN, Ries SK (1977) “Superoxide dismutases: I. Occurrence in higher plants”. Plant Physiol 59:309.

Gill SS, Tuteja N (2010) Reactive oxygen species and antioxidant machinery in abiotic stress 519 tolerance in crop plants. Plant Physiol Biochem 48(12):909-930.

Gomes-Junior RA, Moldes CA, Delite FS, Gratão PL, Mazzafera P, Lea PJ, Azevedo RA (2006) Nickel elicits a fast antioxidant response in Coffea arabica cells. Plant Physiol Biochem 44:420-429.

Gratão P, Monteiro C, Antunes A, Peres L, Azevedo R (2008) Acquired tolerance of tomato (Lycopersicon esculentum cv. Micro-Tom) plants to cadmium-induced stress. Ann Appl Biol 153:321-333.

Jin, M., Li, L., Xu, C., Wen, Y., and Zhao, M. (2010) Estrogenic activities of two synthetic pyrethroids and their metabolites. J Environ Sci (China) 22, 290-6.

Khan MU, Sessitsch A, Harris M, Fatima K, Imran A, Arslan M, Shabir G, Khan QM, Afzal M. 2014. Crresistant rhizo-and endophytic bacteria associated with Prosopis juliflora and their potential as phytoremediation enhancing agents in metal-degraded soils. Front Plant Sci.5:755.

Kumar, S., and Trivedi, P. K. (2018). Glutathione S-Transferases: Role in Combating Abiotic Stresses Including Arsenic Detoxification in Plants. Frontiers in plant science, 9(751).

doi:10.3389/fpls.2018.00751. 
Lehotay, S. J., de Kok, A., Hiemstra, M., and Van Bodegraven, P. (2005) Validation of a fast and easy method for the determination of residues from 229 pesticides in fruits and vegetables using gas and liquid chromatography and mass spectrometric detection. J AOAC Int 88, 595-614.

Maksymiec W (2007) Signaling responses in plants to heavy metal stress. Acta Physiol Plant 9:177-187.

Matsumoto E, Kawanaka Y, Yun SJ, Oyaizu H. (2009). Bioremediation of the organochlorine pesticides, dieldrin and endrin, and their occurrence in the environment. Appl Microbiol Biotechnol 84:205-216.

McCutcheon SC, Schnoor JL. 2003. Phytoremediation: transformation and control of interaction with N and C metabolism. J Exp Bot 55: 1831-1842.

Meyer, B. N., Lam, C., Moore, S., and Jones, R. L. (2013). Laboratory degradation rates of 11 pyrethroids under aerobic and anaerobic conditions. J Agric Food Chem, 61(20), 4702-4708. doi:10.1021/jf400382u.

Miglioranza KSB, de Moreno JEA, Moreno VJ. 2004. Organochlorine pesticides sequestered in the aquatic macrophyte Schoenoplectus californicus (C.A. Meyer) Soják from a shallow lake in Argentina. Water Res 38: $1765-1772$.

Miguel AS, Ravanel P, Raveton R. 2013. A comparative study on the uptake and translocation of organochlorines by Phragmites australis. J Hazard Mater 244- 245:60- 69. 105.

Mishra V, Srivastava G, Prasad SM (2009) Antioxidant response of bitter gourd (Momordica charantia L.) seedlings to interactive effect of dimethoate and UV-B irradiation. Sci Hortic 120:373-378.

Mithofer A, Schulze B, Boland W (2004) Biotic and heavy metal stress response in plants for common signal. FEBS Lett 56:1-4.

Mohammed Hamid Al-Hamdani, N., and Hanumant Narasinhachary, Y. (2011) Endocrine disruptive action of cypermethrin in male mice. Toxicological and Environmental Health Sciences 3, 69-79.

Morgan, M. K., Sheldon, L. S., Croghan, C. W., Jones, P. A., Chuang, J. C ,.and Wilson, N. K. (2007) An observational study of 127 preschool children at their homes and daycare centers in Ohio: environmental pathways to cis- and trans-permethrin exposure. Environ Res 104, 266-74.

Ostiz, S. B., and Khan, S. U. (1994) Nonextractable (bound) residues of cypermethrin in soils. Bull Environ Contam Toxicol53, 907-12.

P. N. Carvalho, C. A. Arias and H. Brix (2016). Removal of the pesticides imazalil and tebuconazole in saturated constructed wetland mesocosms. Water Res 91: 126-136.

Parween T, Jan S, Mahmooduzzafar FatmaT (2012) Evaluation of oxidative stress in Vigna radiata L. in response to chlorpyrifos. Int J Environ Sci Technol 9:605-612. 
Peixoto F., Alves-Fernandes D., Santos D. and Fontainhas-Fernandes A. (2006). Toxicological effects of oxyfluorfen on oxidative stress enzymes in tilapia Oreochromis niloticus. Pest. Biochem. Phys. 85, 91-96.

Prasad SM, Dwivedi R, Zeeshan M (2005a) Growth, photosynthetic electron transport, and antioxidant responses of young soybean seedlings to simultaneous exposure of nickel and UV-B stress.

Photosynthetica 43:177-185.

Romeh, A. A. (2010) Phytoremediation of water and soil contaminated with imidacloprid pesticide by Plantago major, L. Int J Phytoremediation 12, 188-99.

Romeh, A. A. (2015). Evaluation of the phytoremediation potential of three plant species for azoxystrobincontaminated soil. International Journal of Environmental Science and Technology, 12(11), 3509-3518. doi:10.1007/s13762-015-0772-7.

Romeh, A. A. (2015). Evaluation of the phytoremediation potential of three plant species for azoxystrobincontaminated soil. International Journal of Environmental Science and Technology, 12(11), 3509-3518. doi:10.1007/s13762-015-0772-7.

Romeh, A. A. (2016) Efficiency of Rumex dentatus L. leaves extract for enhancing phytoremediation of Plantago major L. in soil contaminated by carbosulfan. Soil and Sediment Contamination: An International Journal 25, 941-956.

Romeh, A. A., and Hendawi, M. Y. (2017) Biochemical interactions between Glycine max L. silicon dioxide (SiO2) and plant growth-promoting bacteria (PGPR) for improving phytoremediation of soil contaminated with fenamiphos and its degradation products. Pesticide Biochemistry and Physiology 142, 32-43.

Romney EM, Neel JW, Nishita H, Olafson JH, Et Larson KE. 1957. Plant uptake of Sr 90. Y 91. Ru 106, Cs 137 and Ce 144 from soils. Soil Sci., 83, 369-376.

Schwitzguébel JP, Schröder P. 2009. Phytotechnologies to promote sustainable land use and improve food safety: Outcomes and outlook from the European COST Action 859. Environ Sci Pollut Res 16: 743744.

Sharifa, A. A ,.Neoh, Y. L., Ismail, M., Osman, K., Abdul Halim, M., Mohamed, J., Mohamed Azman, A. B., and Hing, H. (2008) Effects of Methanol, Ethanol and Aqueous Extract of Plantago major on Gram Positive Bacteria, Gram Negative Bacteria and Yeast. Annals Microscopy 8 April.

Swaileh, K.M., N. Rabay'a, R. Salim, A. Ezzughayyar and A.A. Rabbo. 2001. Concentrations of heavy metals in roadside soils, plants, and landsnails from the West Bank, Palestine. J. Environ. Sci. and Health. A. 36(5): 765-778.

Wang, Q. R., Y.S. Cui, X.M. Liu, Y.T. Dong and P. Christie. 2003. Soil contamination and plant uptake of heavy metals at polluted sites in China. J. Environ. Sci. and Health. A .38 (5): 823-838. 
Wang, W. (1986). Toxicity tests of aquatic pollutants by using common duckweed. Environmental Pollution Series B, Chemical and Physical, 11(1), 1-14. doi:https://doi.org/10.1016/0143-148X(86)900285 .

Willekens $\mathrm{H}$ et al. (1997) Catalase is a sink for $\mathrm{H} 2 \mathrm{O} 2$ and is indispensable for stress defense in $\mathrm{C} 3$ plants. EMBO J 16:4806-4816.

Willey N, 2007. Methods in Biotechnology. vol 23. Phytoremediation Methods and Reviews. Humana Press. Totowa New Jersey.

Ximenez-Embum, P., B. Rodriguez-Sanz, Y. MadridAlbarran and C. Camara. 2001. Uptake of heavy metals by lupin plants in artificially contaminated sand: Preliminary Results. Intern. J. Environ. Anal. Chem. 82 (11-12): 805- 813.

Yanyu S, Changchun S, Songbai J, Junhai C, Jun G, Quandong Z. 2010. Hydroponic uptake and distribution of nitrobenzene in phragmites australis: potential for phytoremediation. Int $\mathrm{J}$ Phytoremediation 12:217-225.

Yin, X., Jiang, L., Song, N., and Yang, H. (2008). Toxic Reactivity of Wheat (Triticum aestivum) Plants to Herbicide Isoproturon. J Agric Food Chem, 56, 4825-4831.

Zhang, J. J. et al (2014). Accumulation and toxicological response of atrazine in rice crops. Ecotoxicology and Environmental Safety, New York, v. 102, n. 2, p. 105-112.

Zubair, M. (2010) Genetic and environmental effects on polyphenols in Plantago major. report at Faculty of Landscape Planning, Horticulture and Agriculture Science, Swedish University of Agriculture Science.

\section{Figures}




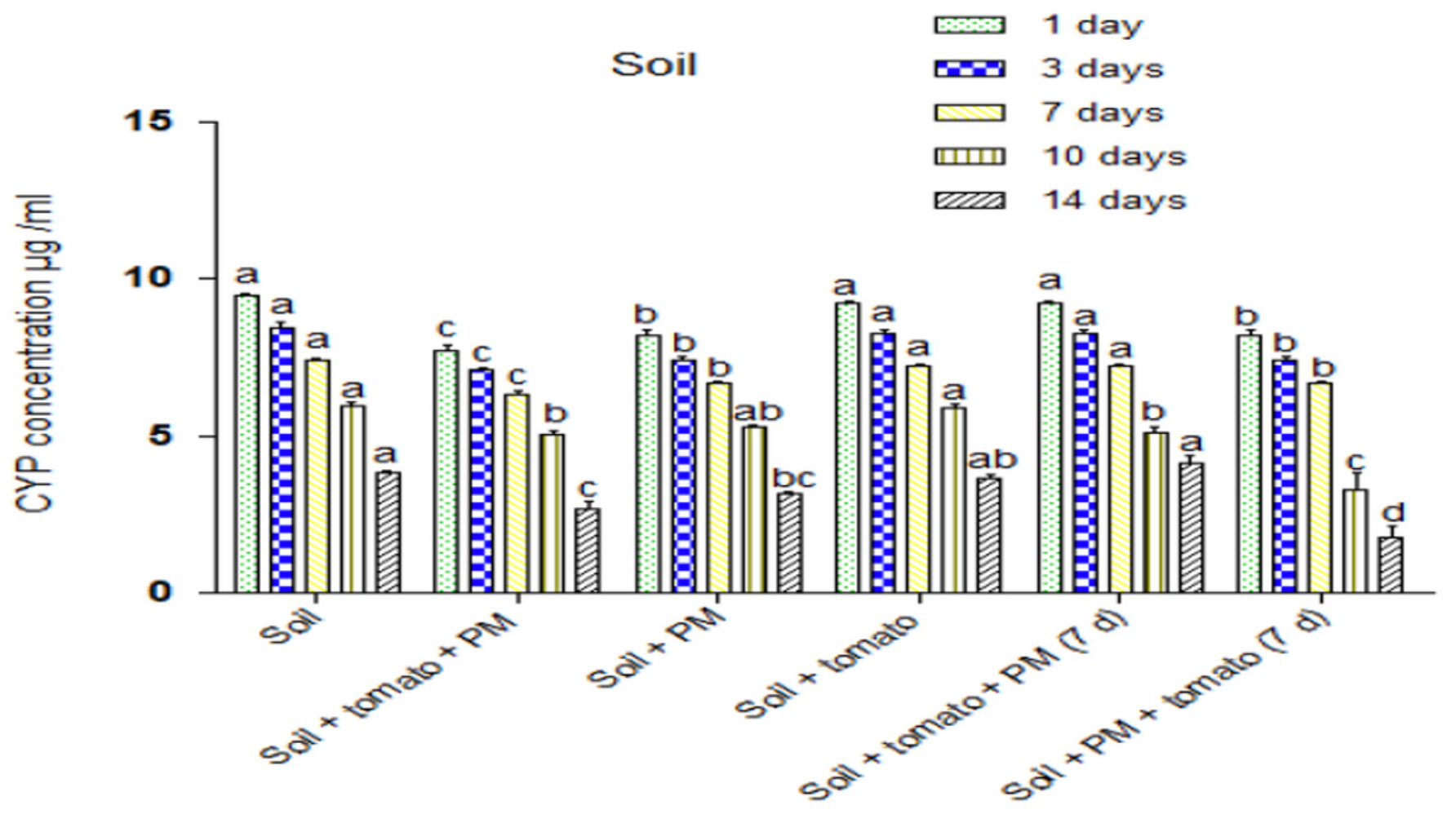

Treatment

\section{Figure 1}

Degradation of CYP in soil planted with two species plants, PM and Tomato. Mean and standard deviation of three replicates are shown. Different letters on top of the bar indicate significant differences $(p<0.05)$ 


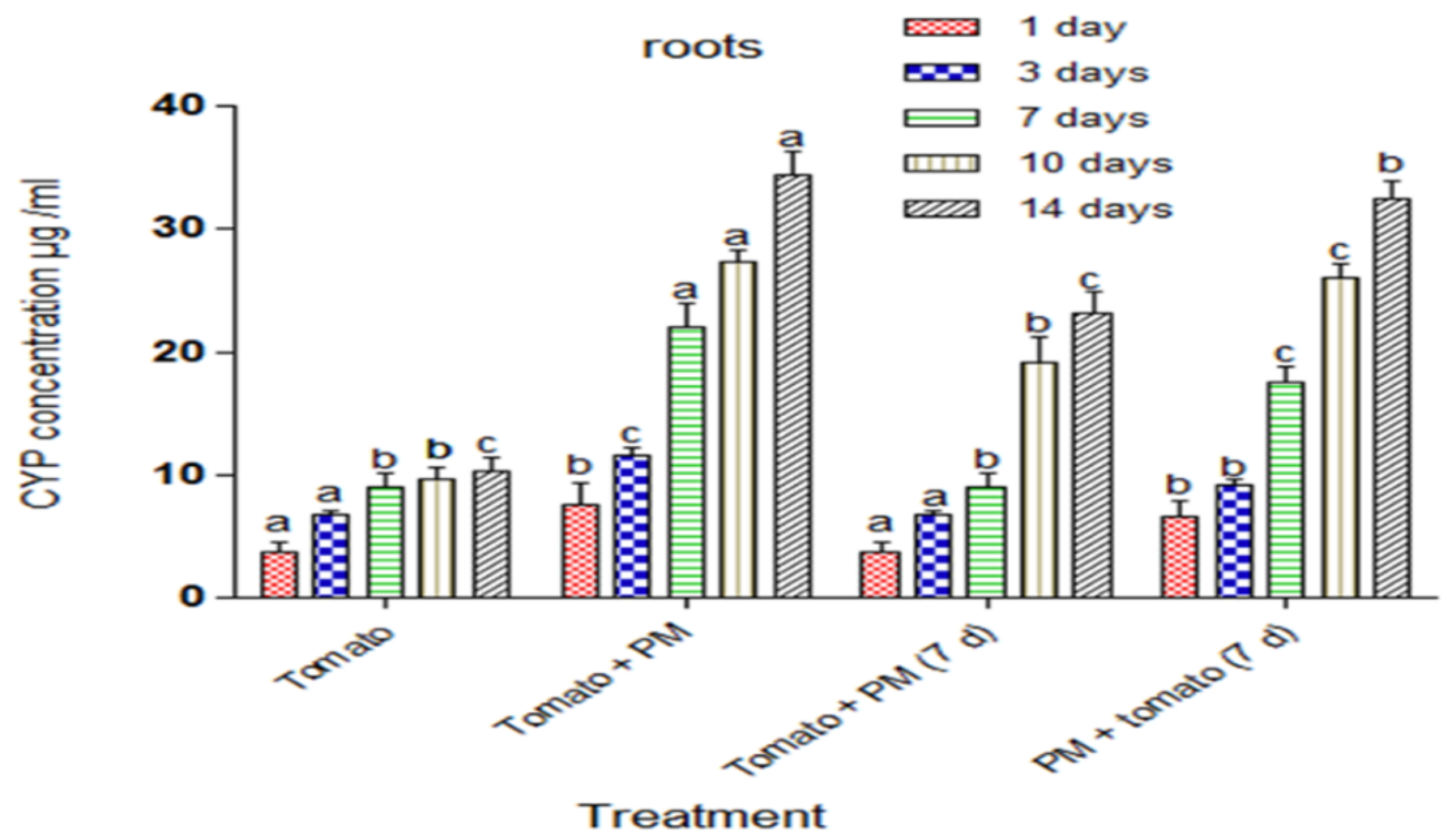

Figure 2

Uptake and translocation of CYP in roots of PM and tomato. Mean and standard deviation of three replicates are shown. Different letters on top of the bar indicate significant differences $(p<0.05)$ 


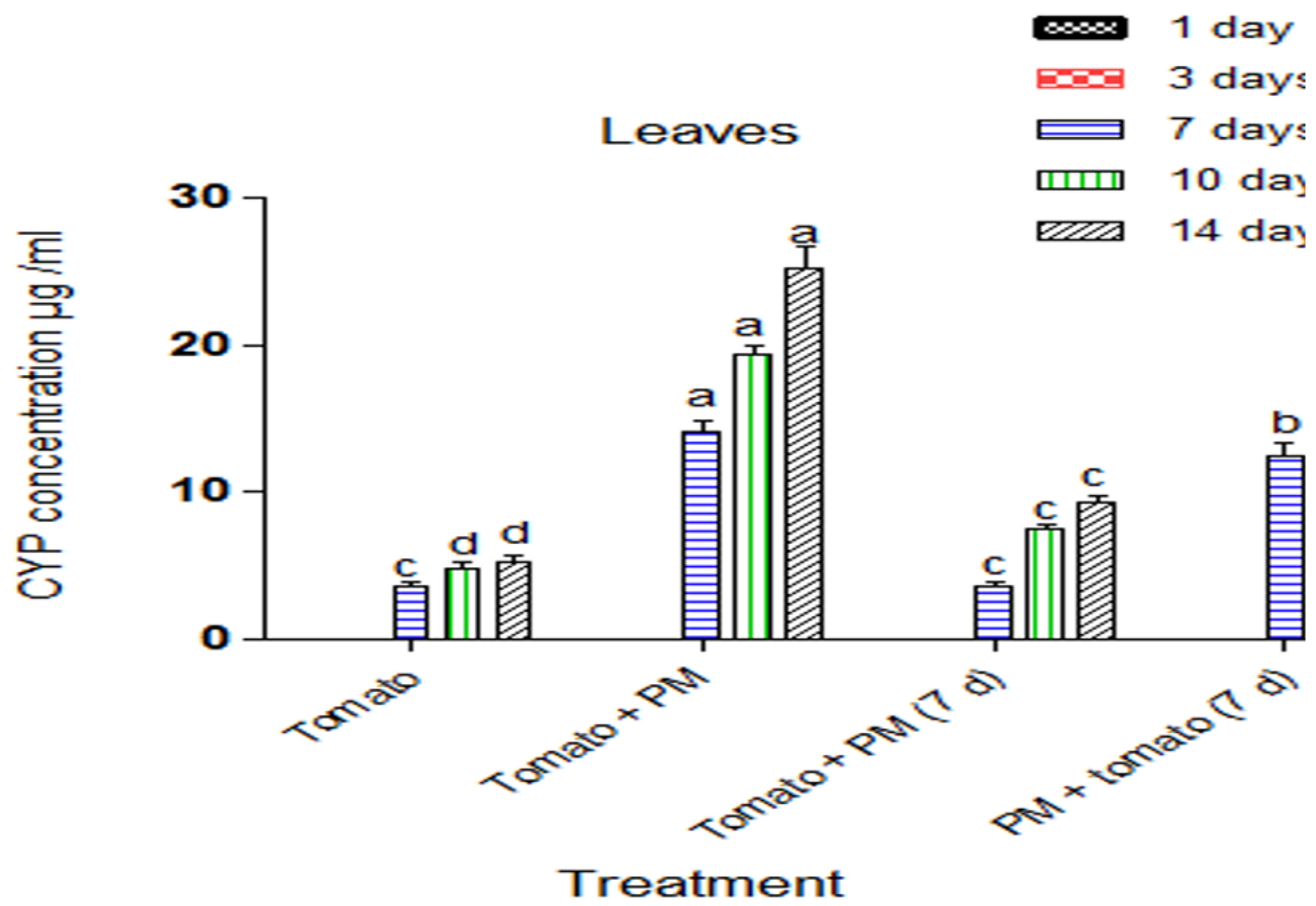

Figure 3

Uptake and translocation of CYP in roots of PM and tomato. Mean and standard deviation of three replicates are shown. Different letters on top of the bar indicate significant differences $(p<0.05)$ 


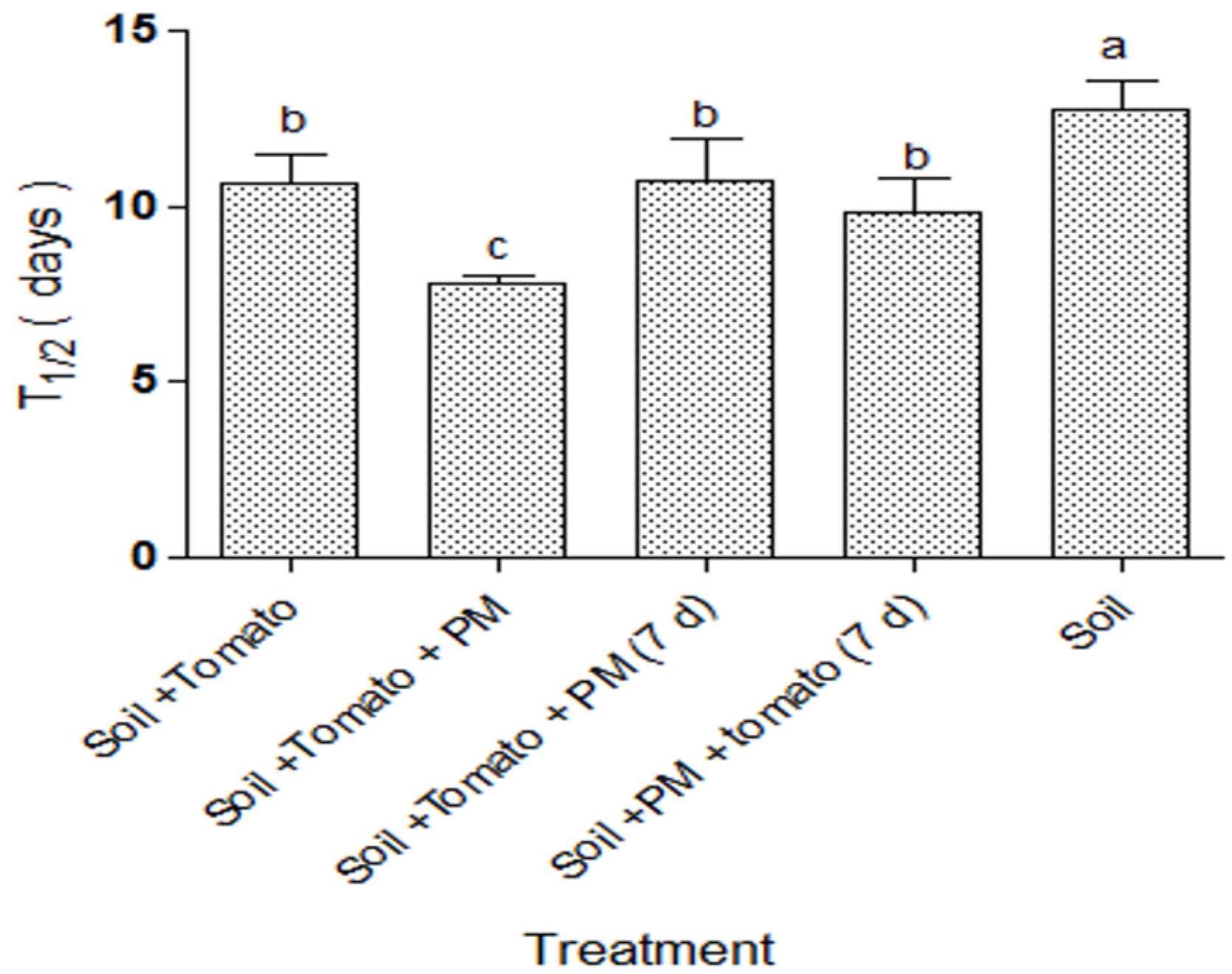

Figure 4

The half-life (t1/2) of CYP in different soil treatments. Mean and standard deviation of three replicates are shown. Different letters on top of the bar indicate significant differences $(p<0.05)$ 

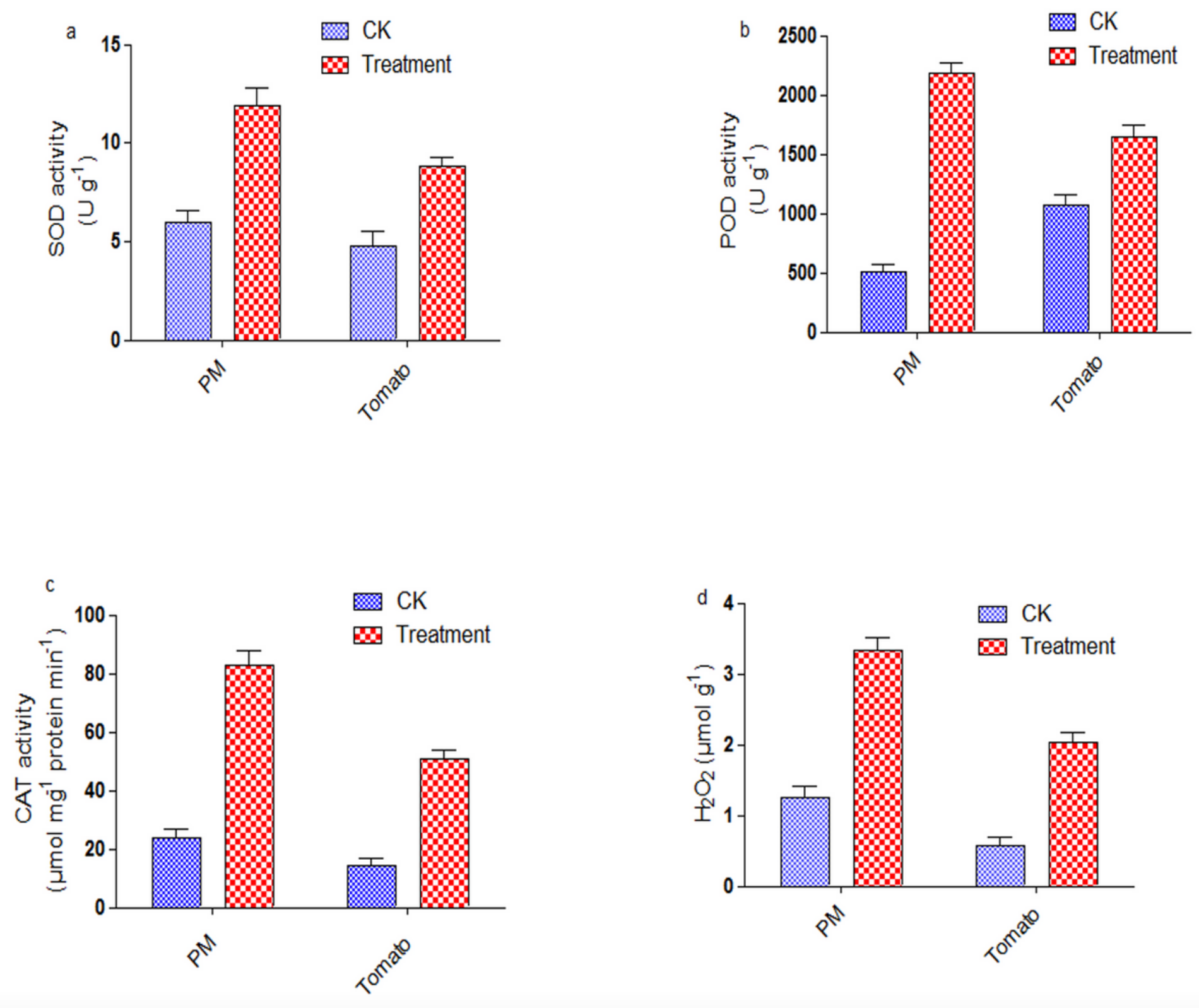

Figure 5

Determination of SOD, POD, CAT and H2O2 in PM and tomato roots after 8 days from CYP exposure. Mean and standard deviation of three replicates indicate significant differences $(p<0.05)$ 